\title{
Enhancing the Digital Literacy of Pre-Service Biology Teacher through Animal Systematics Course
}

\author{
Reni Ambarwati \\ Department of Biology \\ Universitas Negeri Surabaya \\ Surabaya, Indonesia \\ reniambarwati@unesa.ac.id
}

\author{
Ulfi Faizah \\ Department of Biology \\ Universitas Negeri Surabaya \\ Surabaya, Indonesia \\ ulfifaizah@unesa.ac.id
}

\author{
Dwi Anggorowati Rahayu \\ Department of Biology \\ Universitas Negeri Surabaya \\ Surabaya, Indonesia \\ dwirahayu@unesa.ac.id
}

\begin{abstract}
Digital literacy is one of the important skills that must be mastered by Biology Teacher. An effort has been applied to integrate the learning of Animal Systematics with the training of digital literacy for pre-service biology teachers. This research aimed to evaluate the digital literacy of pre-service teachers that programming the Animal Systematics Course as well as evaluate the need for the course related to the implementation of digital literacy training. This research used mixed method, involving one group shoot case study. The samples were 25 pre-service biology teachers programming Animal Systematics Course. The course implemented projectbased tasks, namely animal systematics mini-research, scientific writing, and phylogenetics reconstruction. The digital literacy of pre-service teachers was evaluated based-on four indicators, namely internet searching, hypertextual navigation, content evaluation, and knowledge assembly. The data of the digital literacy score was analyzed descriptive-qualitatively. The result revealed that literacy digital of pre-service biology teacher can be enhanced through the learning process of Animal Systematics Course. The scores of internet searching, hypertextual navigation, content evaluation, and knowledge assembly rose significantly, reached a score of 85 on average. It can be concluded that digital literacy can be trained during the learning process of animal systematics. This research also recommends the need for an electronic book of animal systematics as supporting learning resources.
\end{abstract}

Keywords- digital literacy; animal systematics course; preservice teacher

\section{INTRODUCTION}

Information literacy associated with information and communications technology (ICT) literacy is known as digital literacy. The term digital literacy was first introduced by Gilster [1]. Gilster [1] defined digital literacy as the ability to understand and use information from various digital sources. Bawden [2] added that digital literacy is rooted in computer literacy and information literacy. Digital literacy is not only dealing with computer and technology, but also some skills and ability, for example the awareness, attitudes, and abilities of individuals to precisely use digital tools and facilities for identifying, accessing, managing, integrating, evaluating, analysis, and synthesis digital resources, building new knowledge, and communicating with others, in the context of specific life situations and required self-regulated skills [2][3][4]. Nowadays, the advance of technology encourages learners to access and use online and digital materials [5]. Hence, the digital literacy is urgently needed to be trained to the students, especially pre-service teachers.

Several efforts to practice and train digital literacy in learning have been done, for example, Chan et al. [6] who practice digital literacy through storytelling. In addition, blended learning that utilizes ICT has also been applied, for example by Suana et al. [7]. However, not all teachers understand and master digital literacy. Kurnianingsih et al. [8] reported that not all teachers and librarians mastered digital literacy, but this ability could be improved through training activities, including the learning activities in the class.

In the learning of Biology, digital literacy is very necessary for the students because many learning resources can be obtained from the internet, for example by utilizing various pages (websites) and learning media that can be downloaded by teachers and students. Animal Systematics is one of the courses that must be programmed by pre-service Biology teachers. This course discusses the diversity and kinship relationships of animals. One of the course learning outcomes is the application of science and technology in animal systematic studies. Hence, the digital literacy can be trained during the learning of this course. This study set out to investigate the digital literacy of pre-service teacher that programming the Animal Systematics Course as well as evaluates the need of the course related to the implementation of digital literacy training.

\section{METHOD}

\section{A. Participants of the Study}

This research used mixed method, involving one group shoot case study. The participants were 25 pre-service biology teachers programming Animal Systematics Course.

\section{B. Course Design and Treatment}

The Animal Systematic Course implemented projectbased tasks, namely animal systematics mini-research, scientific writing, and phylogenetic reconstruction. Preservice teachers worked in pairs completing the tasks. First, designing mini-research of animal systematics. Pre-service teachers chose the topic of study, and then defined the research questions. Pre-service teachers developed and wrote a complete proposal of mini research. During the 
accomplishment of this task, the lectures provided guidance and encouraged the pre-service teachers to use various and reliable online recourses. By doing this task, the participants were trained the internet searching (major), hypertextual navigation (major), content evaluation (major), and knowledge assembly (minor).

The second task, pre-service teachers wrote scientific articles. This course designed a chance for field study at a beach where the participants can found and learn many phyla of invertebrates. The findings of this field study were reported and written as an article. During identification and writing the article, the participants were guided to use various online resources. By doing this task, the participants were train the internet searching (major), hypertextual navigation (major), content evaluation (major), and knowledge assembly (major).

The last task was phylogenetic reconstruction. In this task, the participants reconstruct the phylogenetic of fish based on morphological characters and reconstruct the phylogenetic of mammals using molecular character, namely the gene retrieved from the gene bank. By accomplishing this task, the participants were expected to learn about the new program and website for phylogenetic reconstruction. During doing this task, the participants were train the internet searching (minor), hypertextual navigation (major), content evaluation (minor), and knowledge assembly (major).

After finishing the three tasks, the participant fulfilled the questionnaire about their perception about their digital literacy and the acquisition of digital literacy.

\section{Data Analysis}

The digital literacy of pre-service teachers was evaluated based-on four indicators, namely internet searching, hypertextual navigation, content evaluation, and knowledge assembly. The digital literacy score was analyzed based on the proposal of mini-research, article, and the result of phylogenetic reconstruction. The perception of participants as well as their responses was analyzed descriptivequantitatively.

\section{RESULTS AND DISCUSSION}

The course of Animal Systematics integrated the learning of animal systematics with the training of digital literacy for pre-service teachers. During the learning of this course, the participants were trained internet searching, hypertextual navigation, content evaluation, and knowledge assembly by doing the tasks. As educators, we can developed intervention strategies to improve the information literacy of internet users [9]. This also can be applied in the learning of animal systematics

The participants successfully finished writing proposal of mini-research. There were thirteen proposals about invertebrates and vertebrates wrote by the participants (Table I). During the learning the material of certain topic, preservice teachers as participants can be trained the digital literacy. In this digital era, the digital information becomes mushrooming. Hence, the students and the educators require the critically analysis to use the information [10][11][5].
TABLE I. MINI RESEARCH OF ANIMAL SYSTEMATICS

\begin{tabular}{|c|c|c|}
\hline No & Title of Mini Research & $\begin{array}{l}\text { The Object of } \\
\text { Study }\end{array}$ \\
\hline 1. & $\begin{array}{l}\text { The potency of bivalves: Isognomonidae } \\
\text { as an anti-bacterial liquid soap against } \\
\text { Staphylococcus aureus and Escherichia } \\
\text { coli }\end{array}$ & $\begin{array}{l}\text { Mollusca: } \\
\text { Bivalvia }\end{array}$ \\
\hline 2. & $\begin{array}{l}\text { Effect of processing of pellet made from } \\
\text { the shell of golden snail (Pomace } \\
\text { canaliculata) on the growth of catfish } \\
\text { (Clarias gariepinus) }\end{array}$ & $\begin{array}{l}\text { Mollusca: } \\
\text { Gastropoda }\end{array}$ \\
\hline 3. & $\begin{array}{l}\text { Holo-ray ("Holothuroidea scabra" spray } \\
\text { for wound healing formula): black sea } \\
\text { cucumber extract spray for therapy of } \\
\text { diabetic ulcer infected by Staphylococcus } \\
\text { aureus }\end{array}$ & $\begin{array}{l}\text { Echinodermata: } \\
\text { Holothuroidea }\end{array}$ \\
\hline 4. & $\begin{array}{l}\text { The Potency of Pinctada maculata flesh } \\
\text { extract as an antibacterial }\end{array}$ & $\begin{array}{l}\text { Mollusca: } \\
\text { Bivalvia }\end{array}$ \\
\hline 5. & $\begin{array}{l}\text { The effectiveness of the gills of Tilapia } \\
\text { (Oreochromis niloticus) as a marker for } \\
\text { the water quality level in its cultivation }\end{array}$ & $\begin{array}{l}\text { Vertebrata: } \\
\text { Pisces }\end{array}$ \\
\hline 6. & $\begin{array}{l}\text { Biodiversity recognition: Pseudobiceros } \\
\text { hancokcanus as a tool of public education } \\
\text { on Tulungagung Popoh beach on } \\
\text { Platyhelminthes }\end{array}$ & Platyhelminthes \\
\hline 7. & $\begin{array}{l}\text { Streptococcus mutans antibacterial } \\
\text { composite paste made from milkfish } \\
\text { (Chanos chanos) bone waste }\end{array}$ & $\begin{array}{l}\text { Vertebrata: } \\
\text { Pisces }\end{array}$ \\
\hline 8. & $\begin{array}{l}\text { Comparison of the abundance of brittle } \\
\text { stars (Ophiuroidea) at the Kemiran beach } \\
\text { in Paciran Lamongan, East Java and } \\
\text { Sundak Beach, Gunungkidul, Yogyakarta }\end{array}$ & $\begin{array}{l}\text { Echinodermata: } \\
\text { Ophiuroidea }\end{array}$ \\
\hline 9. & $\begin{array}{l}\text { The in silico test of extract sponge } \\
\text { Euspongia officinalis as an anticancer } \\
\text { compound }\end{array}$ & Porifera \\
\hline 10 & $\begin{array}{l}\text { The condition and potency of hard coral } \\
\text { in the coastal waters of the Papuma } \\
\text { Regency of Jember East Java }\end{array}$ & Cnidaria \\
\hline 11. & $\begin{array}{l}\text { Shell powder of Barbatia foliata to enrich } \\
\text { calcium in animal feed for laying hens }\end{array}$ & $\begin{array}{l}\text { Mollusca: } \\
\text { Bivalvia }\end{array}$ \\
\hline 12. & $\begin{array}{l}\text { Effectiveness of chitosan extracted from } \\
\text { shrimp on the storage time of chicken } \\
\text { eggs }\end{array}$ & $\begin{array}{l}\text { Arthropoda: } \\
\text { Crustacea }\end{array}$ \\
\hline 13. & $\begin{array}{l}\text { Biodiversity recognition: the habit of } \\
\text { feeding wader fish in the river of Bringin } \\
\text { Village, Taman, Sidoarjo }\end{array}$ & $\begin{array}{l}\text { Vertebrata: } \\
\text { Pisces }\end{array}$ \\
\hline
\end{tabular}

After field study in Lamongan Kemantren Beach, the participant wrote their findings in scientific articles (Table II).

TABLE II. ARTICLES OF ANIMAL SYSTEMATICS

\begin{tabular}{|l|l|c|}
\hline No & \multicolumn{1}{|c|}{ Title of Articles } & $\begin{array}{c}\text { The Object of } \\
\text { Study }\end{array}$ \\
\hline 1. & $\begin{array}{l}\text { Identification of Isognomon sp. (Bivalvia: } \\
\text { isognomonidae) from Lamongan } \\
\text { Kemantren Beach }\end{array}$ & $\begin{array}{c}\text { Mollusca: } \\
\text { Bivalvia }\end{array}$ \\
\hline 2. & $\begin{array}{l}\text { Species richness of Muricidae gastropods } \\
\text { on Lamongan Kemantren Beach }\end{array}$ & $\begin{array}{c}\text { Mollusca: } \\
\text { Gastropoda }\end{array}$ \\
\hline 3. & $\begin{array}{l}\text { Diversity of species and potential of sea } \\
\text { cucumbers as alternative livelihoods in the } \\
\text { coastal environment of the Lamongan } \\
\text { Kemantren Beach, East Java }\end{array}$ & $\begin{array}{c}\text { Echinodermata: } \\
\text { Holothuroidea }\end{array}$ \\
\hline 4. & $\begin{array}{l}\text { Identification of Pinctada maculata shells } \\
\text { on the Lamongan Kemantren Beach }\end{array}$ & $\begin{array}{c}\text { Mollusca: } \\
\text { Bivalvia }\end{array}$ \\
\hline 5. & $\begin{array}{l}\text { Identification of gobi (Rhinogobius sp.) } \\
\text { Based on morphological characteristics on } \\
\text { the coast of Lamongan Kemantren Beach }\end{array}$ & Vertebrata: \\
Pisces
\end{tabular}




\begin{tabular}{|l|l|c|}
\hline 8. & $\begin{array}{l}\text { Profile of Ophiactis savignyi in the coastal } \\
\text { area of Paciran Lamongan, East Java }\end{array}$ & $\begin{array}{c}\text { Echinodermata: } \\
\text { Ophiuroidea }\end{array}$ \\
\hline 9. & $\begin{array}{l}\text { Euspongia officinalis sponge from Paciran } \\
\text { Beach, Lamongan }\end{array}$ & Porifera \\
\hline 10 & $\begin{array}{l}\text { Diversity of corals on the coast of, } \\
\text { Lamongan Kemantren Beach, East Java }\end{array}$ & Cnidaria \\
\hline 11. & $\begin{array}{l}\text { Potential of Barbatia foliata (Bivalvia: } \\
\text { Arciidae) shells in the coastal area of } \\
\text { kemongan village lamongan }\end{array}$ & $\begin{array}{c}\text { Mollusca: } \\
\text { Bivalvia }\end{array}$ \\
\hline 12. & $\begin{array}{l}\text { Morphometric identification and } \\
\text { characteristics of coral reef fish in the } \\
\text { waters of the Lamongan Kemantren Beach }\end{array}$ & $\begin{array}{c}\text { Arthropoda: } \\
\text { Crustacea }\end{array}$ \\
\hline 13. & $\begin{array}{l}\text { Morphometry studies and sixbar grouper } \\
\text { fish at the Lamongan Kemantren Beach }\end{array}$ & $\begin{array}{c}\text { Vertebrata: } \\
\text { Pisces }\end{array}$ \\
\hline
\end{tabular}

While doing the first and second tasks, the participants were taught how to search reputable article using a search engine and indexed database for example Google Scholar and DOAJ (Directory of Open Access Journal) which are free. In addition, the participants also encouraged using reliable websites. Based on the evaluation, the participants are able to use various websites to support their writing of mini-research proposal and scientific articles (Table III). Hence, during writing proposal of mini-research and scientific articles, the participants learn in internet searching, hypertextual navigation, content evaluation, and knowledge assembly. As the websites well developed, more information can be gained in the website, hence the website can be used as potential learning resources [12]. Prior to the used of the websites, the user has to evaluate the content. In addition, we can choose the reliable website [9].

TABLE III. VARIOUS WEBSITES USED BY THE PARTICIPANTS

\begin{tabular}{|c|c|c|c|}
\hline No & Websites & URL & Topics \\
\hline 1. & $\begin{array}{l}\text { World Register } \\
\text { of Marine } \\
\text { Species }\end{array}$ & $\begin{array}{c}\text { http://www.marinespecies. } \\
\text { org/ }\end{array}$ & $\begin{array}{l}\text { Taxonomy of } \\
\text { marine } \\
\text { species }\end{array}$ \\
\hline 2. & IUCN Red List & $\begin{array}{l}\text { https://www.iucnredlist.or } \\
\mathrm{g} /\end{array}$ & $\begin{array}{l}\text { Conservation } \\
\text { status of } \\
\text { animals }\end{array}$ \\
\hline 3. & $\begin{array}{l}\text { National Center } \\
\text { for } \\
\text { Biotechnology } \\
\text { Information }\end{array}$ & $\begin{array}{l}\text { https://www.ncbi.nlm.nih. } \\
\text { gov/ }\end{array}$ & $\begin{array}{c}\text { Gene } \\
\text { Information } \\
\text { and } \\
\text { Publication }\end{array}$ \\
\hline 4. & CITES & https://www.cites.org/ & $\begin{array}{l}\text { Trading } \\
\text { Status of } \\
\text { animals }\end{array}$ \\
\hline 5. & Fish database & $\begin{array}{l}\text { https://www.fishbase.in/se } \\
\text { arch.php }\end{array}$ & Fish \\
\hline 6. & Wildsingapore & $\begin{array}{l}\text { https://www.wildsingapor } \\
\text { e.com }\end{array}$ & $\begin{array}{l}\text { Animals, } \\
\text { especially } \\
\text { marines }\end{array}$ \\
\hline 7. & $\begin{array}{l}\text { Animal } \\
\text { Diversity Web } \\
\text { (ADW) }\end{array}$ & https://animaldiversity.org & Animals \\
\hline 8. & Porifera & $\begin{array}{l}\text { https://ucmp.berkeley.edu/ } \\
\text { porifera/poriferalh.html }\end{array}$ & Porifera \\
\hline
\end{tabular}

While doing the last tasks, namely phylogenetic and dendogram reconstruction, the participants were also trained the indicators of digital literacy, but mainly focused on hypertextual navigation. This task only involved one internet resources, namely Gene Bank of NCBI but provided great chances to developed the hypertextual navigation ability. Besides, this task introduced some programs used in bioinformatics, for instance NTSYSpc version 2.01, Bioedit, Clustal X, and Mega 5.
Based on results of the three tasks, the digital literacy of the participants was evaluated. The scores ranged 83 up to 90 (the average was $85.08 \pm 2.37$ ). This finding indicated that the digital literacy can be trained during delivery of the lessons. All of participants $(100 \%)$ agree that they can improve their ability on internet searching and knowledge assembly. The also gave some positive feedback, as follows.

"I learn how to search journals using good keywords" (participant 3)

"My ability on internet searching was greatly improved because I have to search many trusted articles as references for my writing" (participant 4)

"This task adding knowledge related to credible websites to identify animal species, etc." (participant 5)

"We get some tips, for example, detailed keywords can simplify internet searching” (participant 8)

"With this activity, I came to know the Web address of animals that are trusted and believed to be true, so that I have no problem to find references about animals" (participant 11)

"The writing of mini-research proposal practices the ability to search for literature such as journals on the internet" (participant 22)

"Knowing the web-sites that can be used to facilitate the classification and description of animals" (participant 23)

“Train us to search research journals" (participant 24)

The participants were also gave similar responses about the benefit of this course to improve their ability of knowledge assembly. The also gave some positive feed back, as follows.

"Interpreting a research or writing the finding of research can improve the ability of knowledge assembly" (participant 3)

"Yes, when working on scientific article, we have to identify fish, by comparing using fish database" (participant 4)

"Based on direct observations and comparing with previous research form journals articles, we can improve our ability in knowledge assembly" (participant 6)

"Yes ... I learned a lot to write data from the task of making scientific articles” (participant 10)

"We are able to describe diagnostic characteristics, from general to specific" (participant 13)

"We write scientific article using trusted literature such as published research results in a journals" (participant 14)

"You can select the data on the web and used it as references in article writing" (participant 22)

Fast majority of participants $(92 \%)$ agree that they can improve their ability on hypertextual navigation. Two participants disagree that the tasks of animal systematic course can improve their ability in hypertextual navigation. The comments were as follows.

"Because students are guided stage by stage, so students are less independent in using the features of websites" (participant 8)

“Don't really use website features" (participant 15) 
During the course, the participants were guided step by step by the lectures because they were still learning. Besides, less website feature were used to simplify the learning process. It was expected that the participant can apply the principle digital literacy independently in the future. The next finding was most participants (96\%) agree that they can improve their ability on content evaluation. Only one participant disagreed that the tasks of animal systematic course can improve their ability in content evaluation. The comment was as follows.

"The task can't improve the ability of content evaluation because there is still lack of information about reliable news sources or websites for access related to biology on the internet" (participant 2)

In general the participant realized that they can improve their digital literacy during the learning of animal systematics by doing writing of mini-research proposal, scientific writing, and phylogenetic reconstruction. The last task gave less contribution on internet search and content evaluation, on the other hand give more contribution on hypertextual navigation (Fig. 1) This finding was in accordance with the research design.

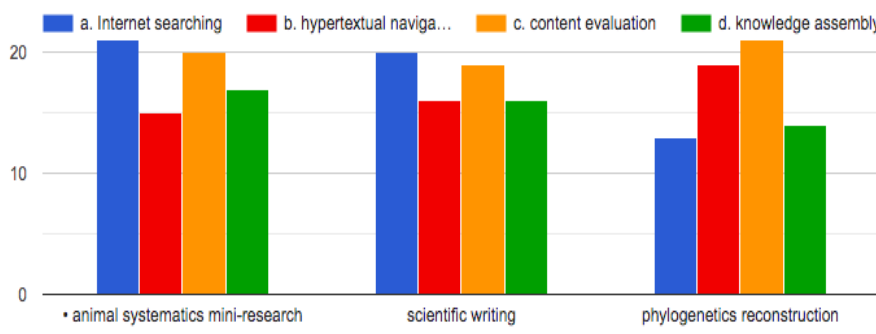

Fig. 1. The perception of participants about the indicators of digital literacy that can be trained during the task

All participants stated that in the future they will evaluate the results of the internet searching prior to the using of the materials. All participants give positive responses to the integration of digital literacy in the animal systematics course. More than half of participants $(56 \%)$ recommended the use of electronic book to facilitate the training of digital literacy while delivery the lesson. Some previous researches used electronic book in the science teaching [13][14].

The results of questionnaire revealed that an electronic book expected to has link to the trusted website and scientific journals (Fig. 2). This will enable the reader to be familiar with reliable resources. Another opinion, related to the use of image and species description to help the reader in identification. Pictures proved can enhance learning [15].

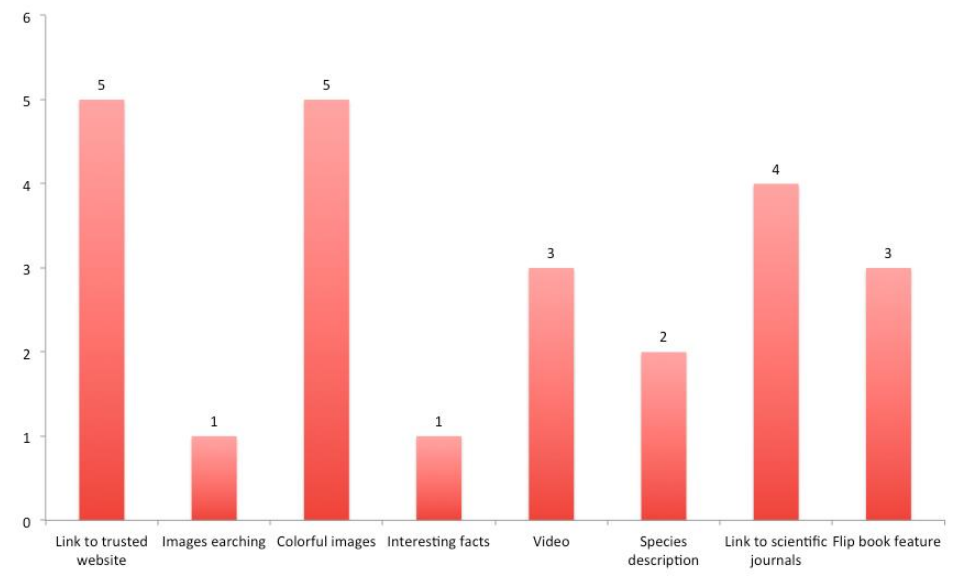

Fig. 2. The expected profile of electronic book that can be used to train the digital literacy in animal systematics course by participants

\section{CONCLUSION}

It can be concluded that digital literacy can be trained during the learning process of animal systematics. This research also recommends the need for an electronic book of animal systematics as supporting learning resources, which has special features that can facilitate pre-service teacher to improve their digital literacy.

\section{ACKNOWLEDGMENT}

We are grateful to the Faculty of Mathematics and Natural Sciences for the funding of the research. Thanks to PBU2017 class and the co-assistant team of Animal Systematics for the participation in this study.

\section{REFERENCES}

[1] P. Gilster, Digital Literacy. New York: Wiley, 1997.

[2] D. Bawden, "Information and digital literacies: A review of concepts,” J. Doc., vol. 57, no. 2, pp. 218-259, 2001.

[3] A. Martin, "A European framework for digital literacy," Nord. J. Digit. Lit., vol. 2, no. 1, pp. 151-161, 2006.

[4] J. A. Greene, S. B. Yu, and D. Z. Copeland, "Measuring critical components of digital literacy and their relationships with learning," Comput. Educ., vol. 76, pp. 55-69, 2014.

[5] B. A. Knight, "Teachers' use of textbooks in the digital age," Cogent Educ., vol. 2, no. 1, pp. 1-10, 2015.

[6] B. S. K. Chan, D. Churchill, and T. K. F. Chiu, "Digital Literacy Learning In Higher Education Through Digital Storytelling Approach," J. Int. Educ. Res., vol. 13, no. 1, pp. 1-16, 2017.

[7] W. Suana, N. Maharta, I. D. P. Nyeneng, and S. Wahyuni, "Design and implementation of Schoology-Based Blended Learning Media for Basic Physics I Course," J. Pendidik. IPA Indones., vol. 6, no. 1, pp. 170-178, 2017.

[8] I. Kurnianingsih, Rosini, and N. Ismayati, "Upaya Peningkatan Kemampuan Literasi Digital bagi Tenaga Perpustakaan Sekolah dan Guru di Wilayah Jakarta Pusat Melalui Pelatihan Literasi Informasi," J. Pengabdi. Kpd. Masy., vol. 3, no. 1, pp. 61-76, 2017.

[9] M. J. Metzger and A. J. Flanagin, "Credibility and trust of information in online environments: The use of cognitive heuristics," J. Pragmat., vol. 59, pp. 210-220, 2013.

[10] C. M. Tang and L. Y. Chaw, "Digital Literacy: A Prerequisite for Effective Learning in a Blended Learning Environment?," Electron. J. e-Learning, vol. 14, no. 1, pp. 54-65, 2016.

[11] Y. L. Ting, "Tapping into students' digital literacy and designing negotiated learning to promote learner autonomy," Internet High. Educ., vol. 26, pp. 25-32, 2015.

[12] E. Hargittai, "An update on survey measures of web-oriented digital literacy," Soc. Sci. Comput. Rev., vol. 27, no. 1, pp. 130$137,2009$. 
[13] L. P. Pradina and A. Suyatna, "Atom Core Interactive Electronic Book to Develop Self Efficacy and Critical Thinking Skills.," Turkish Online J. Educ. Technol. - TOJET, vol. 17, no. 1, pp. 1723, 2018.

[14] C. Lai, "Integrating E-books into Science Teaching by Preservice Elementary School Teachers," J. Educ. Sci. Environ. Heal., vol. 2, no. 1, p. 57, 2015.

15] S. Herrlinger, T. N. Höffler, M. Opfermann, and D. Leutner, "When Do Pictures Help Learning from Expository Text? Multimedia and Modality Effects in Primary Schools," Res. Sci. Educ., vol. 47, no. 3, pp. 685-704, 2017. 